\title{
Growth of Lactococcus lactis in milk and rennet curd: influence of the level of inoculation
}

\author{
C Favrot, JL Maubois \\ Laboratoire de recherches de technologie laitière, Inra, 65, rue de St-Brieuc, \\ 35042 Rennes cedex, France
}

(Received 2 March 1995; accepted 31 October 1995)

\begin{abstract}
Summary - The growth of Lactococcus lactis subsp lactis CNRZ 1076 (prt+) and CNRZ 1075 (prt) was followed in milk and rennet curd inoculated at levels ranging from $10^{2}$ to $10^{6} \mathrm{cfu} / \mathrm{mL}$. Growth inhibition was observed in rennet curd inoculated with less than $10^{4} \mathrm{cfu} / \mathrm{mL}$ of $L$ lactis CNRZ 1076, suggesting a correlation with growth in colonies and low diffusion coefficients of nutrients and/or end-products such as $\mathrm{H}^{+}$and lactate. As a consequence, at low levels of inoculation acidification developed more slowly in rennet curd than in liquid milk. The growth rate of $L$ lactis CNRZ 1075 (prt) in rennet curd was decreased in liquid and renneted milk. However, the maximum population level was higher in renneted milk than in liquid milk. This stimulation led to a more complete acid pH development in curd than in milk and was probably related to the release of peptides by chymosin activity. Microstructure studies provided evidence for colonies developing in liquid milk and rennet curd inoculated at low levels. The size of the colonies inversely depended on the level of inoculation.
\end{abstract}

level of inoculation / Lactococcus lactis / growth / milk / rennet curd / acidification / bacterial colonies / scanning electron microscopy

Résumé - Croissance de Lactococcus lactis dans le lait et le coagulum présure : influence du taux d'inoculation. L'effet du taux d'inoculation $\left(10^{2}\right.$ à $\left.10^{6} \mathrm{ufc} / \mathrm{mL}\right)$ sur la cinétique de croissance de Lactococcus lactis subsp lactis CNRZ 1076 (prt ${ }^{+}$et CNRZ 1075 (prt) était étudié dans le lait et dans le coagulum présure. Lorsque le taux d'inoculation était inférieur à $10^{4} \mathrm{ufc} / \mathrm{mL}$, la croissance de la souche non protéolytique CNRZ 1075 était ralentie, aussi bien dans le lait que dans le coagulum présure. Dans le coagulum présure cependant, le niveau de population atteint en fin de croissance était supérieur, ce qui conduisait à un $\mathrm{pH}$ final nettement inférieur à celui de la culture sur lait. Pour ces mêmes taux d'inoculation, la souche protéolytique CNRZ 1076 était également inhibée, mais uniquement dans le coagulum présure. La cinétique de croissance dans le lait était indépendante du taux d'inoculation. Ces résultats sont à relier aux observations réalisées sur les cultures en microscopie optique et en microscopie électronique à balayage qui montrent qu'en dessous d'un certain seuil d'inoculation ( $10^{4} \mathrm{ufc} / \mathrm{mL}$ ) la croissance s'effectue sous forme de colonies isolées. Il est vraisemblable que les cellules situées au cœur des colonies ne se trouvent pas dans des conditions optimales de croissance.

taux d'inoculation / croissance/ Lactococcus lactis / lait / coagulum présure / acidification / colonies bactériennes / microscopie électronique à balayage 


\section{INTRODUCTION}

Lactic acid bacteria have been studied indepth for nearly a century and much is known about nutrient requirements (Reiter and Oram, 1962), transport system (Konings et al, 1989), proteolytic systems (Smid et al, 1991) and to a large extent, their growth in milk. The current view is that growth of lactic acid bacteria, especially lactococci and streptococci is limited in milk because of, i) the low level of available essential nitrogenous nutrients (Mills and Thomas, 1981; Juillard and Richard, 1989); and ii) the concomitant inhibiting actions of high lactate concentration and low $\mathrm{pH}$ (Longsworth and Mac Innes, 1936; Bergère and Hermier, 1968; Otto et al, 1980). Lack of nitrogenous nutrients is cancelled for fast strains of starter bacteria which possess a cell wall proteinase (Hugenholtz et al, 1987). The hydrolysis of caseins supplies cells with peptides that are translocated across the membrane and used for growth to high cells densities (Juillard et al, 1994). On the other hand, the increasing lactic acid concentration causes gradual inhibition of growth (Rogers and Whittier, 1928).

During cheese making, growth of starter bacteria may occur to some extent in coagulated milk, according to the cheese type. One can wonder whether rennet action on milk affects the growth of these bacteria since: i) peptides are released from casein hydrolysis by chymosin and pepsin; ii) coagulated paracaseins as substrates for proteinase are structured in a solid network; and iii) solute diffusion may be different in rennet curd than in liquid milk.

A century ago, interesting studies showed that spotting defects seen in Swiss type cheese resulted from occurrence of colonies of bacteria (Burri, 1898; Thöni and Alleman, 1910). Brown and red spotting defects were ascribed to the genus Propionibacterium whereas colonies of lactic acid bacteria (rods and cocci) were likely the cause of a black spotting defect. A more recent study (Baer et al, 1992) has shown that the brown spotting defect only appeared if the population level of propionibacteria in cheese milk was low $(<100 \mathrm{cfu} / \mathrm{mL})$. Moreover, evidence for the general occurrence of small colonies of different species of bacteria in cheese has already been shown. These reports either dealt with the difficulty of counting bacteria in cheese because of their heterogeneous dispersion (Naylor and Sharpe, 1958; Dean et al, 1959) or were investigations on cheese microstructure (Hansson et al, 1966; Rousseau and Le Gallo, 1990). Though numerous data about growth of entrapped bacteria in porous matrices exist (Karel and Robertson, 1989; Yabannavar and Wang, 1991; Cachon and Diviès, 1993), the effect of milk coagulation by rennet on growth of lactic acid bacteria is still unknown. The purpose of this work was to characterize the growth of mesophilic starters in milk and rennet curd as a function of their level of inoculation.

\section{MATERIALS AND METHODS}

\section{Milk and UF retentate culture media}

Skim milk powder made from 'Bactocatch' treated raw skim milk was obtained as described by Schuck et al (1994). Milk culture medium was prepared by reconstituting $10 \mathrm{~g}$ powder in $90 \mathrm{~g}$ autoclaved distilled water at room temperature. After 5 min mixing, reconstituted milk was cooled down to $0^{\circ} \mathrm{C}$ in thawing ice before rennet addition and inoculation. The same batch of powder was used for all the assays.

To prepare UF retentate, bulk skim milk (Compagnie Laitière Européenne, Montauban, France) was pasteurized $\left(75^{\circ} \mathrm{C}, 15 \mathrm{~s}\right)$ and ultrafiltered at $50^{\circ} \mathrm{C}$ up to a volume concentration ratio (VCR) of 3 or 5 using a Carbosep M1 membrane cut-off 70000 (Techsep, Miribel, France). The UF retentate was cooled down to room temperature $\left(20^{\circ} \mathrm{C}\right)$ before rennet addition and inoculation. 


\section{Bacteria cultures and inoculum preparation}

Lactococcus lactis CNRZ 1076 (prt) and CNRZ 1075 (prt) were from the CNRZ collection (Jouyen-Josas, France). Stock cultures were maintained at $-20^{\circ} \mathrm{C}$ in $\mathrm{M} 17$ broth (Biokar, Beauvais, France) with $15 \% \mathrm{w} / \mathrm{w}$ glycerol added. For each experiment $0.2 \mathrm{~mL}$ of each culture was inoculated into $10 \mathrm{~mL} \mathrm{M17}$ broth and incubated overnight at $30^{\circ} \mathrm{C}$. The cultures were then centrifuged at room temperature $(4000 \mathrm{~g}, 10 \mathrm{~min})$ and cell pellets were washed with saline water $(8.5 \mathrm{~g} / \mathrm{L} \mathrm{NaCl})$.

Washing procedure was repeated once before optical density at $650 \mathrm{~nm}$ was adjusted to ca 0.30 with a spectrophotometer (DU 7400, Beckman Instruments, Gagny, France). This suspension was then used to inoculate reconstituted milk and UF retentate at levels ranging from $10^{2}$ to $10^{6} \mathrm{cfu} / \mathrm{mL}$.

\section{Milk coagulation, non-clotting milk and chymosin denaturation}

Crystalline chymosin, purified according to Garnot and Mollé (1982) was a gift of D Mollé (INRA, Laboratoire de Recherches en Technologie Laitière, 65 , rue de St Brieuc, 35042 Rennes cedex, France). $0.5 \mathrm{mg}$ crystalline chymosin was dissolved in $1 \mathrm{~mL}$ sterile water $(\mathrm{pH} 6)$ and stocked at $4^{\circ} \mathrm{C}$. After inoculation, if necessary, $30 \mu \mathrm{L}$ of a $500 \mathrm{mg} / \mathrm{L}$ concentrated chymosin solution was added per $100 \mathrm{~mL}$ of cooled reconstituted milk. Before warming it up to $30{ }^{\circ} \mathrm{C}$ in a water bath, milk was divided into $1 \mathrm{~mL}$ quantities in tubes for growth measurement and into $20 \mathrm{~mL}$ quantities in tubes for acidification measurements.

Non-clotting milk was prepared by incubating reconstituted skim milk with $5 \%(\mathrm{w} / \mathrm{w})$ cation exchange resin Chelex 100, sodium form, Biotechnology Grade (Bio Rad, Ivry-sur-Seine, France) for $20 \mathrm{~min}$ at room temperature. $\mathrm{pH}$ was adjusted to 6.65 with a $1 \mathrm{~N} \mathrm{HCl}$ solution.

Denatured chymosin was obtained in two ways: i) heating at $100{ }^{\circ} \mathrm{C}$ for $10 \mathrm{~min}$; and ii) incubating at $43^{\circ} \mathrm{C}$ and $\mathrm{pH} 9$ for $24 \mathrm{~h}$.

\section{Milk acidification monitoring}

$\mathrm{pH}$ development was followed with a multi $\mathrm{pH}$ meter MPM 400 (Solomat, Evvry, France) in $40 \mathrm{~mL}$ sterile tubes containing $20 \mathrm{~mL}$ milk culture medium. The temperature of the cultures was always $30^{\circ} \mathrm{C}$.

\section{Growth rate estimation}

Experiments on growth of $L$ lactis CNRZ 1076 and 1075 in liquid and renneted milk inoculated with $10^{2}, 10^{3}, 10^{4}$ and $10^{6} \mathrm{cfu} / \mathrm{mL}$ were repeated three times. No significant differences were noted between repetitions of each treatment. To compare growth in liquid milk and in coagulated milk, the following method was used for all the experiments: inoculated cooled milk (with chymosin added or not) was divided among 10 separate sterile $5-\mathrm{mL}$ tubes, each containing $1 \mathrm{~mL}$ milk. Every tube was warmed up to $30^{\circ} \mathrm{C}$ in a water bath. Growth of $L$ lactis CNRZ 1076 and CNRZ 1075 was static. Tubes taken at intervals were quickly cooled down to $0{ }^{\circ} \mathrm{C}$ in thawing ice. Milk or rennet curd was diluted in $9 \mathrm{~mL}$ sterile saline water and the mix was homogenized with an Ultra-Turrax at $20000 \mathrm{rpm}$ for $30 \mathrm{~s}$ at room temperature. $L$ lactis enumeration was assessed by plating sample dilutions on M17 agar (Biokar, Beauvais, France) with a spiral plater (Interscience, St Nom-la-Bretèche, France). Plates were incubated for $24 \mathrm{~h}$ at $30^{\circ} \mathrm{C}$ before reading with a colony counter by image analysis SCAN 500 (Interscience, St Nom-la-Bretèche, France). The growth rates were expressed according to Monod's equation (1958):

$$
\mu=\frac{1}{\text { doubling time }}\left(h^{-1}\right)
$$

\section{Cultures in buffered milk}

To assess whether the inhibition of lactococci was related to the decrease in $\mathrm{pH}$ within colonies, $20 \mathrm{mmol} / \mathrm{L}$ (final concentration) phosphate buffer prepared as follows was added to milk culture medium: a stock solution consisting of $1.72 \mathrm{~g}$ of $\mathrm{CaHPO}_{4}, 2 \mathrm{H}_{2} \mathrm{O}$ (Merck, Nogent-surMarne, France) and $1.88 \mathrm{~g}$ of $85 \%$ concentrated $\mathrm{H}_{3} \mathrm{PO}_{4}$ solution (Merck, Nogent-sur-Marne, France) was adjusted to $\mathrm{pH} 6.80$ with a $1 \mathrm{~N}$ $\mathrm{NaOH}$ solution (ca $40 \mathrm{~mL}$ ) and brought to a volume of $100 \mathrm{~mL}$ with sterile distilled water. Reconstituted milk was prepared by diluting $10 \mathrm{~g}$ skim milk powder in $79 \mathrm{~g}$ sterile distilled water, $1 \mathrm{~mL}$ inoculum and $30 \mu \mathrm{L}$ of either a $500 \mathrm{mg} / \mathrm{L}$ concentrated chymosin solution or sterile distilled water. In order to avoid phosphate precipitate decantation, $100 \mu \mathrm{L}$ of either the phosphate stock solution or sterile distilled water was added 
to culture tubes each containing $900 \mu \mathrm{L}$ of reconstituted milk just before milk began to coagulate, ie, after $40 \mathrm{~min}$ incubation at $30^{\circ} \mathrm{C}$. Throughout this study, the level of inoculation of $L$ lactis CNRZ 1076 was $10^{2} \mathrm{cfu} / \mathrm{mL}$.

\section{Slide culture}

In order to visualize how bacteria grow in milk and rennet curd, slide cultures were made according to a modification of the method of Postgate et al (1961) as follows. Milk was reconstituted using the method of Turner et al (1963) with an aqueous solution of $0.01 \%$ triphenyl 2,3,5 tetrazolium chloride (TTC) (AES, Combourg, France) and $0.05 \%$ arginine (Sigma, St Quentin Fallavier, France). Milk was cooled down to $0^{\circ} \mathrm{C}$, inoculated and divided in two equal parts: to one, $30 \mu \mathrm{L} / 100 \mathrm{~mL}$ chymosin $(500 \mathrm{mg} / \mathrm{L}$ concentrated solution) was added, while the other was untreated. 5- $\mu \mathrm{L}$ milk samples were incubated at $30^{\circ} \mathrm{C}$ between slides sealed with paraffine to avoid evaporation. Photographs were taken at intervals using a microscope Nikon Optiphot, a camera Nikon F 301 (darkfield condenser and objectives $\times 10$ and $\times 40$ ) and an Ektachrome160 ASA Tungsten film.

\section{Scanning electron microscopy (SEM)}

Five $\mathrm{kg}$ of freshly prepared retentate at VCR 5 was cooled down to $30^{\circ} \mathrm{C}$ and divided in two equal parts of $1.8 \mathrm{~kg}$ before inoculation with $L$ lactis CNRZ 1076. Two levels of inoculation were tested, $10^{2}$ and $10^{6} \mathrm{cfu} / \mathrm{mL}$. $40 \mathrm{~mL}$ of a $520 \mathrm{mg} / \mathrm{L}$ concentrated rennet solution (Granday, Beaune, France) was added per $100 \mathrm{~kg}$ of retentate. Each vat was incubated at $30^{\circ} \mathrm{C}$ until the $\mathrm{pH}$ had dropped to a stable value. Samples were regularly taken for scanning electron microscopy assay.

Prisms $(2 \times 5 \times 10 \mathrm{~mm})$ were taken in the middle of coagulated retentate and fixed with a solution of $2.5 \%$ glutaraldehyde (Sigma, St Quentin Fallavier, France) in $10 \mathrm{mmol} / \mathrm{L}$ cacodylate buffer ( $\mathrm{pH}$ 7.2) (Merck, Nogent-surMarne, France), for at least $15 \mathrm{~h}$ according to Rousseau (1988). Glutaraldehyde was removed by washing samples in cacodylate buffer for 1 day, replacing the washing solution five times. Samples were then dehydrated by incubating in aqueous ethanol (Prolabo, Paris, France) solutions of increasing concentration $(10,25,50,75$, $95 \%$ for 20 min each) and three times in absolute ethanol ( $30 \mathrm{~min}$ each). They were dried in carbon dioxide at critical point (Balzers CPD 030), fractured, mounted on aluminium stubs and sputter coated (20 nm) with gold (Balzers SCD 050). Scanning electron microscopy was carried out with a Philips XL 20 microscope at 8 or $12 \mathrm{keV}$.

\section{RESULTS}

\section{Growth of L lactis CNRZ $1076\left(\mathrm{prt}^{+}\right)$}

\section{Effect of inoculation at low levels on the growth of L lactis CNRZ 1076 (prt $^{+}$) in renneted milk}

The growth of $L$ lactis CNRZ 1076 was followed in liquid milk and milk to which $30 \mu \mathrm{L} / 100 \mathrm{~mL}$ chymosin was added. The growth was not affected by chymosin addition if milk was inoculated with more than $10^{6}$ cfu/mL. With a level of inoculation smaller than $10^{6} \mathrm{cfu} / \mathrm{mL}$, the growth was inhibited in renneted milk compared to that in liquid milk.

Figures 1a-c illustrate that the decrease in growth rate occurred at populations of $\mathrm{ca}$ $310^{8}, 310^{7}, 310^{6} \mathrm{cfu} / \mathrm{mL}$ in renneted milk, respectively inoculated with ca $10^{4}, 10^{3}$, and $10^{2} \mathrm{cfu} / \mathrm{mL}$.

As a consequence, at low levels of inoculation, acidification developed more slowly in rennet curd than in liquid milk (fig 2).

Microbial contaminants from chymosin could not account for this phenomenon since the level of population of mesophilic aerophilic flora of the chymosin was very low (less than $1 \mathrm{cfu} / \mathrm{mL}$ ). Moreover, the growth of contaminants from milk powder was very slow in inoculated reconstituted milk and did not differ whether the milk was coagulated or not. Their maximum population level, ca $10^{6} \mathrm{cfu} / \mathrm{mL}$, was achieved after $15 \mathrm{~h}$ of the lactococcal culture. At that time, the minimum population level of $L$ lactis CNRZ 1076 observed over the whole experiments was $10^{B} \mathrm{cfu} / \mathrm{mL}$ (fig 1c).

The inhibition of the growth of $L$ lactis CNRZ 1076 in renneted milk inoculated at a low level was likely caused by milk clot- 

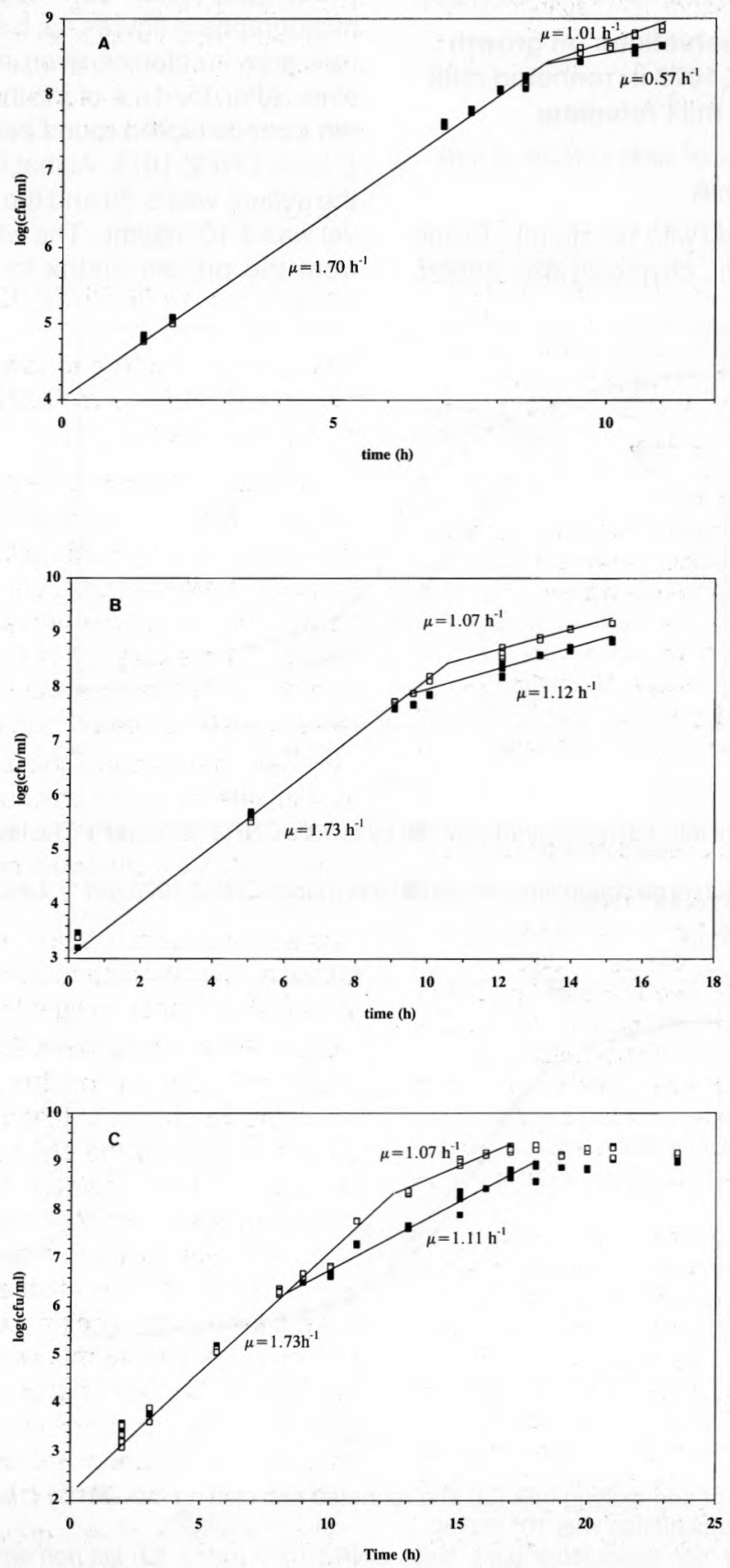

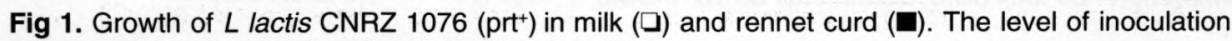
was ca: A) $10^{4} \mathrm{cfu} / \mathrm{mL}$; B) $10^{3} \mathrm{cfu} / \mathrm{mL}$; C) $10^{2} \mathrm{cfu} / \mathrm{mL}$.

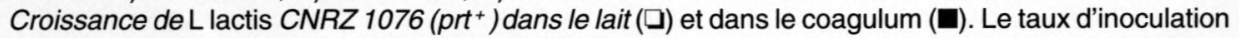
était de : A) $10^{4} \mathrm{ufc} / \mathrm{mL}$; B) $10^{3}$ ufc/mL; C) $10^{2} \mathrm{ufc} / \mathrm{mL}$. 
ting since chymosin action in non-clotting milk had no expected inhibitory effect (fig 3).

Microscopic observations on growth of $L$ lactis CNRZ 1076 in renneted milk and ultrafiltered milk retentate

Light micrographs of slide culture of milk and coagulated milk

Milk was inoculated with $10^{2} \mathrm{cfu} / \mathrm{mL}$. To one part, $30 \mu \mathrm{l} / 100 \mathrm{~mL}$ chymosin was added.
Milk was prepared in thin films trapped between glass slides. Low magnification light micrographs in figures $4 a$, b show that bacteria grew in colonies, even in the liquid milk films. After $15-16 \mathrm{~h}$ of incubation, the rennet curd disrupted round each colony of $L$ lactis CNRZ 1076. At that time, the $\mathrm{pH}$ of the culture was 5.90 and the population level was $310^{8} \mathrm{cfu} / \mathrm{mL}$. The whey separated from the protein matrix forming a liquid

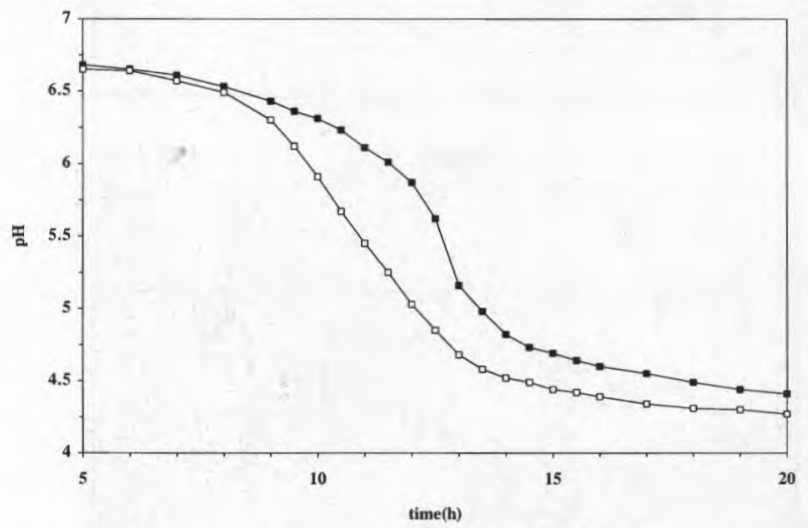

Fig 2. Acidification of milk ( $\square)$ and rennet curd $(\square)$ by L lactis CNRZ $1076\left(\mathrm{prt}^{+}\right)$. The level of inoculation was $10^{4} \mathrm{cfu} / \mathrm{mL}$.

Acidification du lait (口) et du coagulum présure (घ) par L lactis CNRZ 1076 (prt+ ). Le taux d'inoculation était de $10^{4} \mathrm{ufc} / \mathrm{mL}$.

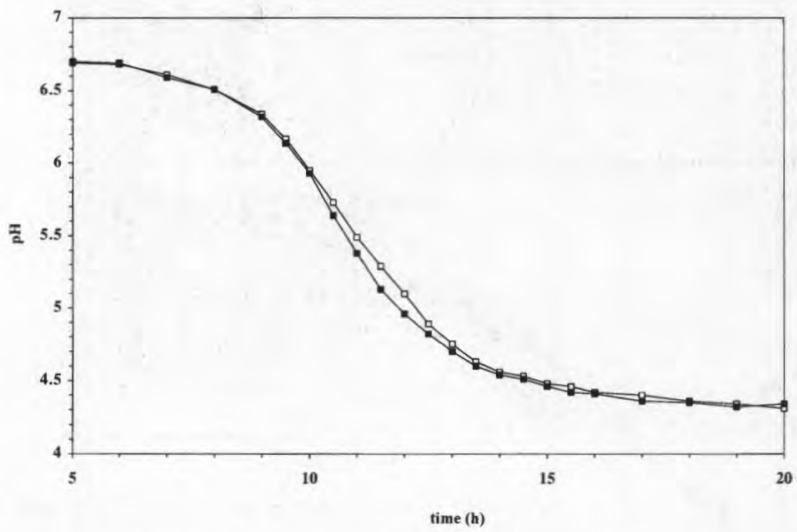

Fig 3. Acidification of non-clotting milk $(\square)$ and renneted non clotting milk ( $\square$ ) by L lactis CNRZ 1076 $\left(\mathrm{prt}^{+}\right)$. The level of inoculation was $10^{4} \mathrm{cfu} / \mathrm{mL}$.

Acidification de lait 'non coagulable' par L lactis CNRZ $1076\left(\mathrm{prt}^{+}\right)$. (コ) lait non emprésuré, (ロ) lait emprésuré. Le taux d'inoculation était de $10^{4} \mathrm{ufc} / \mathrm{mL}$. 

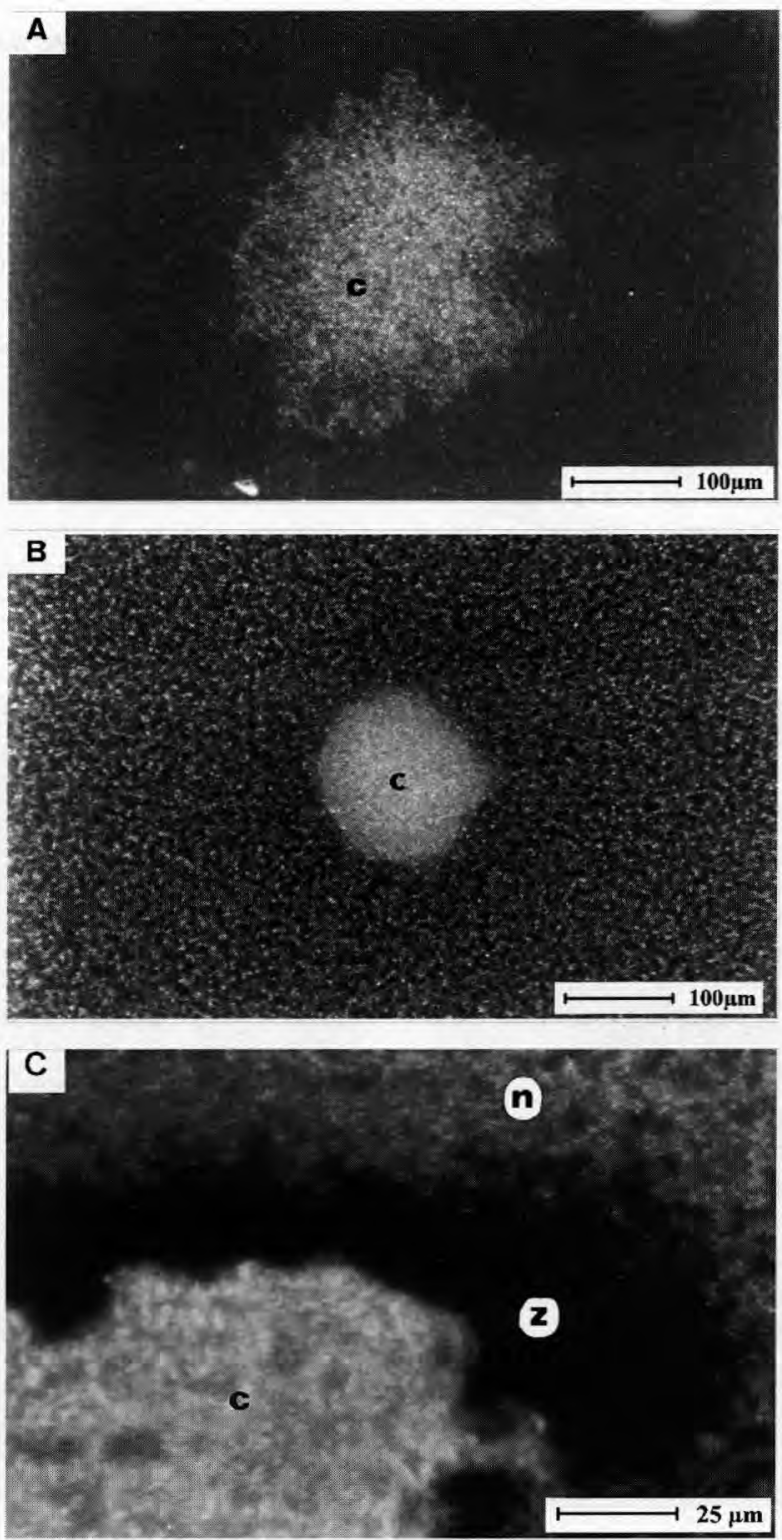

Fig 4. Colony in slide culture of $L$ lactis CNRZ 1076 (prt+) in liquid milk (A) and renneted milk (B) inoculated with $10^{2} \mathrm{cfu} / \mathrm{mL}(\mathrm{t}=14 \mathrm{~h})$; (C) details of the colony border in renneted milk $(\mathrm{t}=17 \mathrm{~h}$; pH 5.90 sample) ; (c) : colony ; (z) : zone of whey : (n) : casein network.

Culture sous lame; colonie dans une culture de L lactis CNRZ $1076\left(\mathrm{prt}^{+}\right)$dans du lait non emprésuré (A) et dans du coagulum présure (B). Le taux d'inoculation était de $10^{2} \mathrm{ufc} / \mathrm{mL}(t=14 \mathrm{~h})$; (C) détail de la périphérie de la colonie $(t=17 \mathrm{~h} ; \mathrm{pH}$ de l'échantillon : 5,90$) ;(c)$ : colonie ; $(z)$ : vacuole de sérum ; $(n)$ : réseau de caséines. 


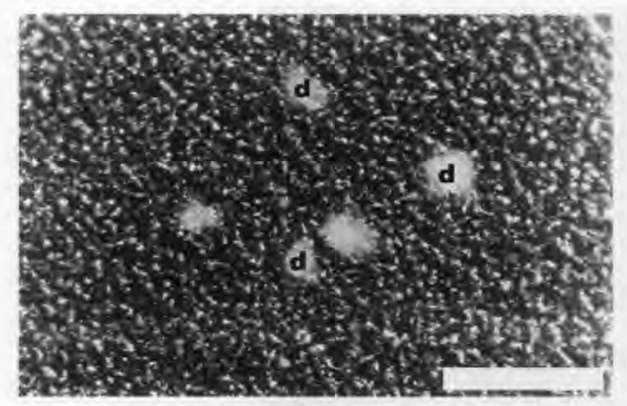

Fig 5. Points of dissemination (d) of cells of $L$ lactis CNRZ 1076 in the whole curd from a slide culture inoculated with $10^{6} \mathrm{cfu} / \mathrm{mL} ; \mathrm{pH} 5.90$ sample. Culture sous lame de L lactis CNRZ $1076\left(p r^{*}\right)$ dans du coagulum présure. Le taux d'inoculation était de $10^{6}$ ufc/ $\mathrm{mL}$, $\mathrm{pH}$ de l'échantillon : 5,90 ). (d) : centres de dissémination des bactéries.
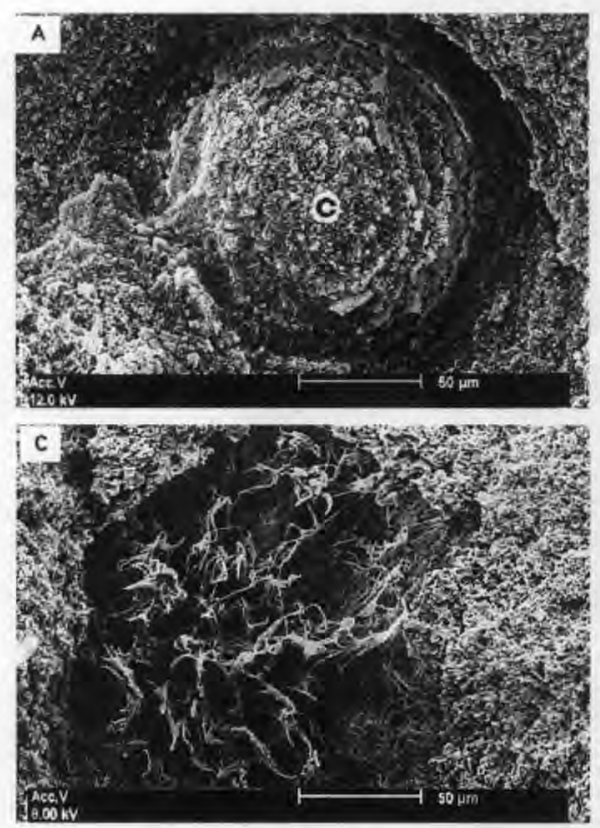

zone (fig 4c) which grew slowly at the periphery of colonies.

If milk was inoculated with $10^{6} \mathrm{cfu} / \mathrm{mL}$, bacteria invaded the whole curd from points of dissemination (fig 5).

\section{Scanning electron microscopy of colonies in coagulated retentate}

At pH 6.30, 5.70, 5.40 and 4.90 samples of UF retentate VCR 5 inoculated with $10^{2}$ or $10^{8} \mathrm{cfu} / \mathrm{mL}$ and to which $30 \mu \mathrm{L} / 100 \mathrm{~mL}$ chymosin was added were examined by SEM. The general aspect of the rennet curd of retentate was in accordance with the findings of Prokopek et al (1976) and Gavaric et al (1989).
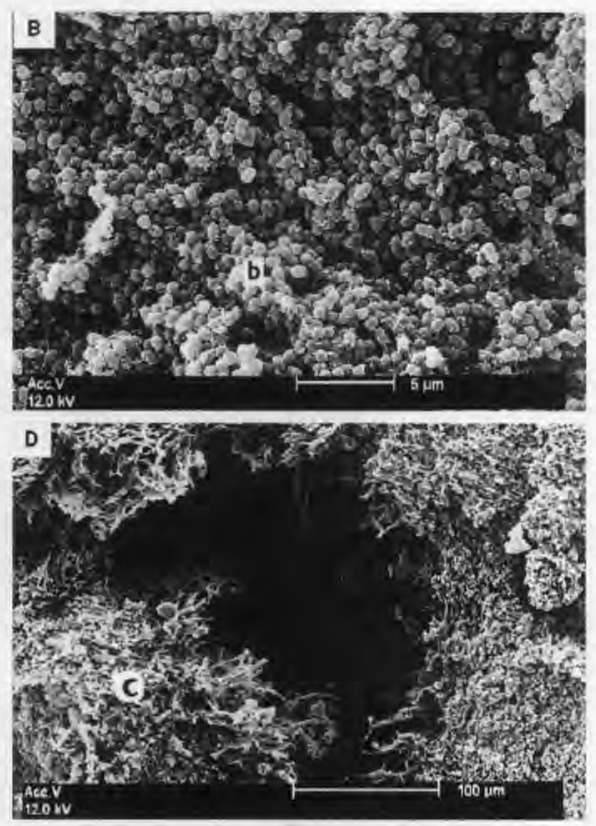

Fig 6. Culture of L lactis CNRZ 1076 (prt *) in renneted VCR5 UF retentate from skim milk; the level of inoculation was $10^{2} \mathrm{cfu} / \mathrm{mL} ; \mathrm{pH} 6.30$ sample. A. Colony (c). B. Bacteria cells in the middle of a colony (b). C. Details of the protein network close to a colony in the same culture; pH 5.70 sample. D. Disruption of the casein network close to a colony (c) in the same culture; $\mathrm{pH} 5.40$ sample.

Culture de L lactis CNRZ 1076 (prt+) dans du rétentat UF emprésuré (facteur de concentration volumique 5). Le taux d'inoculation était de $10^{2}$ ufc/mL. pH de l'échantillon : 6,30. A. Colonie (c). B. Cellules bactériennes au centre d'une colonie (b). C. Détails du réseau de caséines à la périphérie d'une colonie dans la même culture. $\mathrm{pH}$ de l'échantillon 5,70 . D. Fissure du réseau de caséines à la péripherie d'une colonie (c) dans la même culture, $\mathrm{pH}$ de l'échantillon : 5,40. 
The low magnification micrograph of $\mathrm{pH}$ 6.30 samples illustrate that bacteria actually grew in large colonies when the retentate was inoculated with $10^{2} \mathrm{cfu} / \mathrm{mL}$ (fig $6 \mathrm{a}, \mathrm{b}$ ). In the $\mathrm{pH} 5.70$ and 5.40 samples from retentate inoculated with $10^{2} \mathrm{cfu} / \mathrm{mL}$ (fig $6 \mathrm{c}$, d), the rearrangement of casein which appeared to contract in the vicinity of the colonies, led to the formation of large zones of whey, already observed in slide cultures (fig 4c). When the retentate was inoculated with $10^{6} \mathrm{cfu} / \mathrm{mL}$, the colonies were much smaller and closer to each other than in the $10^{2} \mathrm{cfu} / \mathrm{mL}$ inoculated retentate (fig $7 a, b)$.

\section{Growth of L lactis CNRZ 1076 (prt $^{+}$) in liquid and renneted milk supplemented with $2 \mathrm{mg} / \mathrm{mL}$ casein hydrolysate}

As described above, growth and acidification in rennet curd was slower than in liquid milk when low levels of inoculation were used. A possible explanation is a slower degradation of casein by cell wall proteases when bacteria are entrapped in large colonies and casein micelles are immobilized in a network. If casein degradation is involved, addition of peptides should reduce inhibition of growth rate and of acidification development in clotted milk. Milk was supplemented with $2 \mathrm{mg} / \mathrm{mL}$ casein hydrolysate (Casitone, Difco, Detroit, USA). Acidification and growth were followed in liquid milk and milk to which $30 \mu \mathrm{L} / 100 \mathrm{~mL}$ chymosin was added. Addition of casitone to milk did not prevent the inhibitory effect of milk coagulation on acidification and growth of $L$ lactis CNRZ 1076 (prt'): addition of Casitone similarly stimulated acidification and growth whether the milk was coagulated or not (figs 1a, 8).

\section{Growth of $L$ lactis CNRZ 1076 (prt $^{+}$) in rennet curd from phosphated milk and from ultrafiltered milk retentate}

A low $\mathrm{pH}$ in the vicinity of large colonies is a possible explanation of the inhibition of the growth of $L$ lactis CNRZ $1076\left(\mathrm{prt}^{+}\right)$. To test this possibility, bacteria were grown in media of higher buffering capacities as follows: i) rennet curd from milk to which $20 \mathrm{mmol} / \mathrm{L}$ phosphate buffer (final concentration) was added; and ii) rennet curd from ultrafiltered milk retentate VCR 3 . The inoculum level was $10^{2} \mathrm{cfu} / \mathrm{mL}$.

i) Addition of phosphate buffer to a milk culture medium had no effect on growth rates of $L$ lactis CNRZ 1076, whether the
A

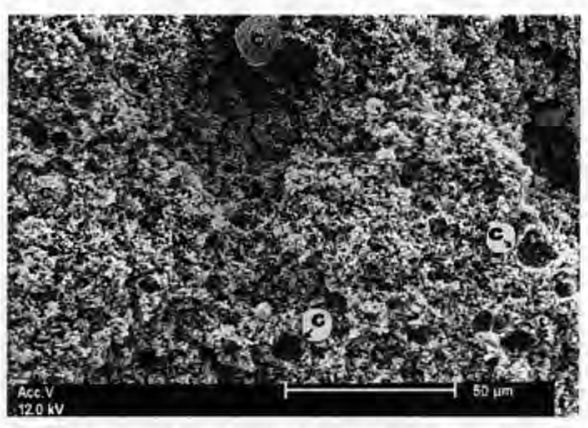

B

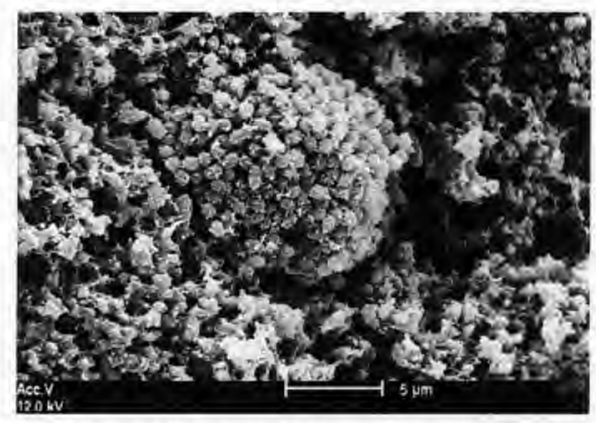

Fig 7. Culture of $L$ lactis CNRZ 1076 (prt) in renneted milk VCR 5 UF retentate from skim milk; the level of inoculation was $10^{6} \mathrm{cfu} / \mathrm{mL}$. $\mathrm{pH} 4.90$ sample. A. Colony (c). B. Details of a colony in the same culture. Culture de L lactis CNRZ $1076\left(\mathrm{prt}^{+}\right)$dans du rétentat UF emprésuré (facteur de concentration volumique 5). Le taux d'inoculation était de $10^{6}$ ufc/mL. $\rho H$ de l'échantillon : 4,90. A. Colonie (c). B. Détails d'une colonie dans la même culture. 


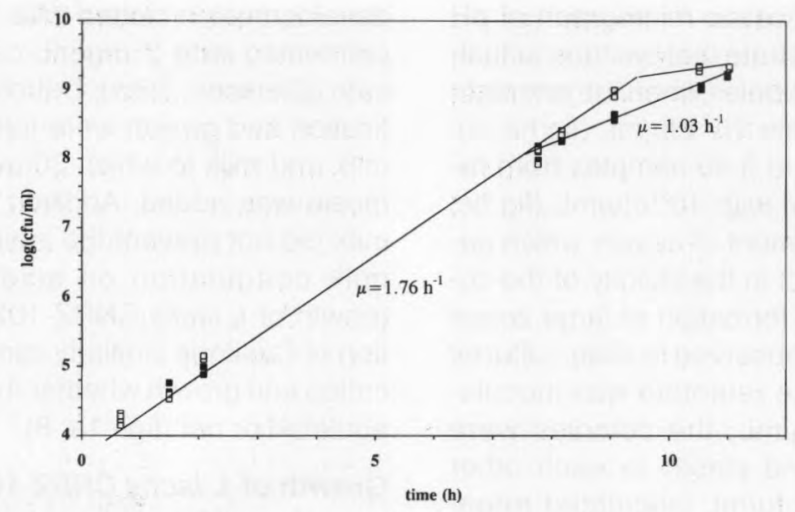

Fig 8. Growth of $L$ lactis CNRZ 1076 (prt) in milk ( $\square)$ and rennet curd (অ) supplemented with $2 \mathrm{mg} / \mathrm{mL}$ casein hydrolysate (Casitone, Difco, Detroit, USA). The level of inoculation was ca $10^{4} \mathrm{cfu} / \mathrm{mL}$.

Croissance de L lactis CNRZ 1076 (prt+ ) dans le lait (口) et dans le coagulum présure (ם) supplémentés avec $2 \mathrm{mg} / \mathrm{mL}$ d'hydrolysat de caséines. (Casitone, Difco, Detroit, États-Unis). Le taux d'inoculation était de $10^{4}$ ufc/mL.

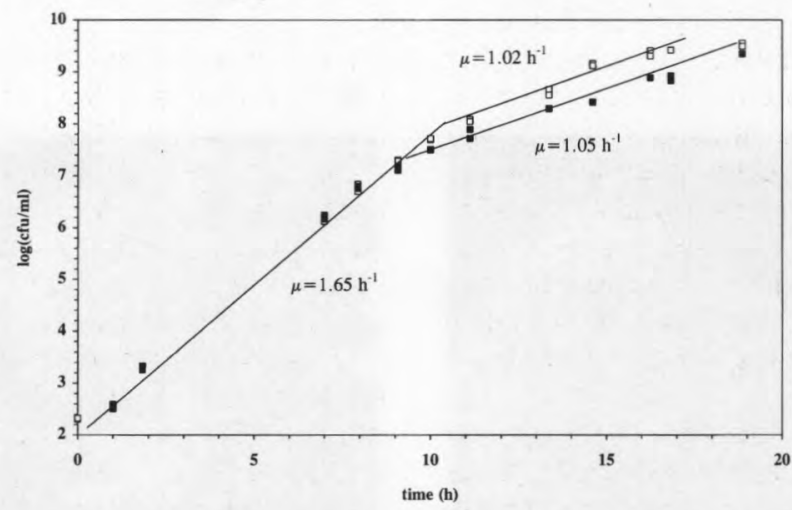

Fig 9. Growth of $L$ lactis CNRZ 1076 in VCR 3 UF retentate inoculated with $10^{2} \mathrm{cfu} / \mathrm{mL}$. (口) growth in liquid retentate, $(\mathbf{E})$ growth in renneted retentate.

Croissance de L lactis CNRZ 1076 (prt) dans un rétentat UF (facteur de concentration volumique 3). (घ) rétentat liquide, (ロ) rétentat emprésuré. Le niveau d'inoculation était de $10^{2} \mathrm{ufc} / \mathrm{mL}$. 
milk was coagulated or not. The phosphate buffer, at the concentration tried, thus failed to relieve the inhibition observed in rennet curd inoculated at a low level.

ii) The media compared in further experiments were pasteurized bulk skim milk and UF retentate, VCR3, prepared from it. A comparison of figure 9 with figure 1c shows that the effect of coagulation on changes in growth rate of $L$ lactis $C N R Z$ 1076 was identical in milk and in retentate. The decrease in growth rate on coagulation occurred as soon as the population level reached ca $310^{6} \mathrm{cfu} / \mathrm{mL}$ in rennet curd from milk (fig $1 \mathrm{c}$ ) or ca $310^{6} \mathrm{cfu} / \mathrm{g}$ in rennet curd from retentate (fig 9 ).

\section{Growth of L lactis CNRZ 1075 (prt)}

\section{Growth of $L$ lactis CNRZ 1075 (prt) in liquid and renneted milk}

Observations of slide cultures grown from low inocula showed that $L$ lactis CNRZ 1075 (prt $^{-}$) also grew in colonies in the liquid and renneted milk films (results not shown).

Figures $10 a, b$ show the growth of $L$ lactis CNRZ 1075 (prt) and the acidification patterns in milk and rennet curd. The level of inoculation was ca $10^{2} \mathrm{cfu} / \mathrm{mL}$. The maximum population level achieved was higher in rennet curd (ca $210^{8} \mathrm{cfu} / \mathrm{mL}$ ) than in liquid milk ( $10^{8} \mathrm{cfu} / \mathrm{mL}$ ) (fig $\left.10 \mathrm{a}\right)$. Consequently, the acidification development was faster in rennet curd than in liquid milk after $20 \mathrm{~h}$ of incubation and led to a lower final $\mathrm{pH}$, ca 4.7-4.8 (fig 10b). This possibly indicates that peptides released by chymosin activity on caseins were a significant source of nitrogen.

Acidification developed more slowly in the rennet curd inoculated with $L$ lactis $C N R Z$ 1075 (prt) than in the rennet curd inoculated with L lactis CNRZ $1076\left(\mathrm{prt}^{+}\right)$. The final $\mathrm{pH}$, above the isoelectric point of casein, and the low acidification rate could explain why, in slide cultures of $L$ lactis CNRZ 1075 ( prt $^{-}$), in contrast to what was observed with L lactis CNRZ 1076 (prt+), no rennet curd disruption developed at the periphery of bacterial colonies, even after $30 \mathrm{~h}$ of incubation (results not shown).

On the other hand, in contrast to what was observed with L lactis CNRZ 1076 (prt ${ }^{+}$), a decrease in growth rate of CNRZ 1075 (pit) was noticed at a population level of ca $310^{6} \mathrm{cfu} / \mathrm{mL}$ in liquid milk as well as in rennet curd (fig 10a).

\section{Growth of $L$ lactis CNRZ 1075 (prt) in liquid and renneted milk supplemented with $2 \mathrm{mg} / \mathrm{mL}$ casein hydrolysate}

The above-mentioned decrease in growth rate at a population level of ca $310^{6} \mathrm{cfu} / \mathrm{mL}$ was similar in liquid culture to which $2 \mathrm{mg} / \mathrm{mL}$ Casitone was added and in the control culture. However, the maximum population level achieved was higher in the supplemented culture than in the control culture (fig 11).

Surprisingly, the inhibition at a population level of ca $310^{6} \mathrm{cfu} / \mathrm{mL}$ was stronger in supplemented renneted culture than in the control renneted culture. No experiment could explain the latter phenomenon.

\section{DISCUSSION}

When the population level used to inoculate milk was less than $10^{6} \mathrm{cfu} / \mathrm{mL}$, the growth of L lactis CNRZ $1076\left(\mathrm{prt}^{+}\right)$significantly differed in liquid milk compared to coagulated milk. In liquid milk, the growth curve shape was in accordance with the observations of Juillard and Richard (1989), whatever the level of inoculation. The transition from the maximum specific growth rate $\left(1.70 \mathrm{~h}^{-1}\right)$ to a lower one $\left(1.01 \mathrm{~h}^{-1}\right)$ when the population level was ca $10^{8} \mathrm{cfu} / \mathrm{mL}$ has been shown to reflect a requirement for amino acids and peptides (Juillard and Richard, 1989). When compared to growth in liquid milk, $L$ lactis CNRZ 1076 was inhibited in rennet curd inoculated with less than $10^{6} \mathrm{cfu} / \mathrm{mL}$. Moreover, the data in this report clearly 

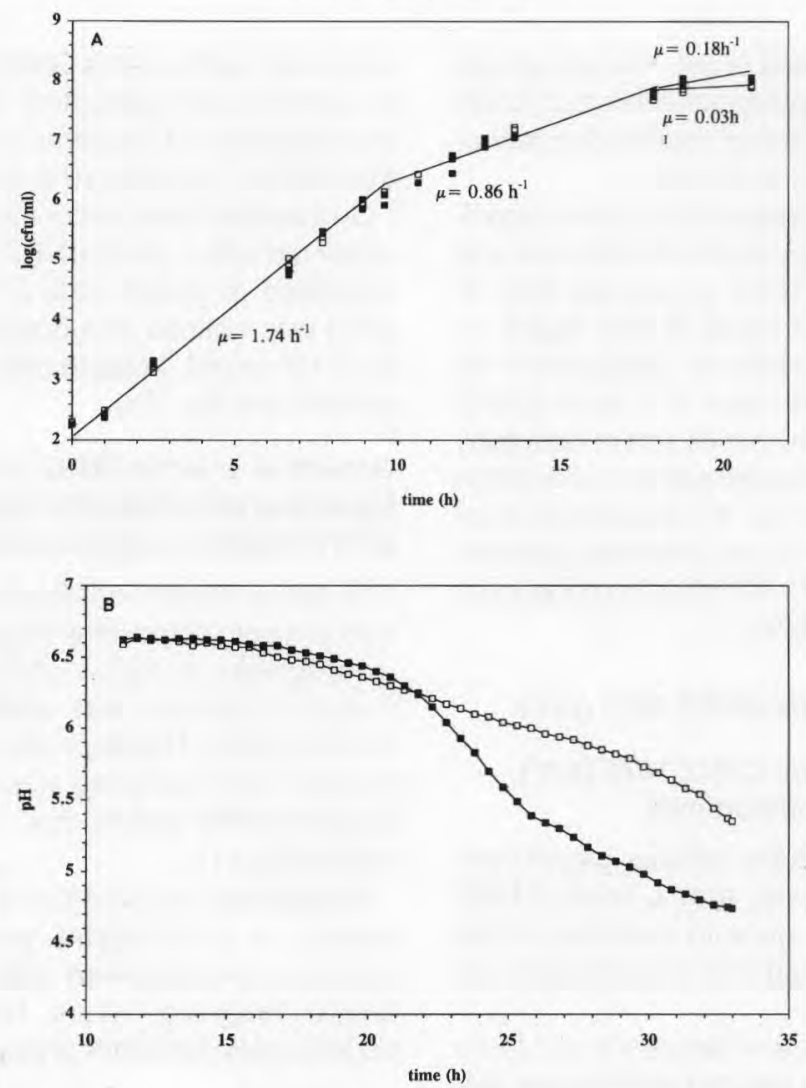

Fig 10. Growth (A) and acidifying (B) activity of L lactis CNRZ 1075 (prt) in milk (D) and in rennet curd (घ) inoculated with $10^{2} \mathrm{cfu} / \mathrm{mL}$.

Croissance (A) et activité acidifiante (B) de L lactis CNRZ 1075 (prt) dans le lait ( $\square$ ) et dans le coagulum

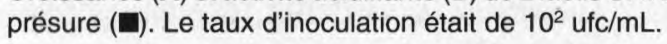

show that the lower the inoculum level, the sooner the occurrence of growth inhibition in rennet curd. More precisely, the decreases in growth rate always occurred as soon as the population level in culture increased by ca $10^{4} \mathrm{cfu} / \mathrm{mL}$ over the initial population.

Similar inhibition was observed in renneted and also in liquid milk, inoculated with low levels of the prt $L$ lactis strain CNRZ 1075.

These results can partly find their explanation in microstructural observations on the growth of $L$ lactis CNRZ 1076 and CNRZ 1075 in rennet curd and in milk. Light and SEM micrographs show that, if the level of inoculation was less than $10^{4} \mathrm{cfu} / \mathrm{mL}$, the lactic acid bacteria examined grew in large colonies in milk or ultrafiltration retentate, in liquid form or coagulated by rennet. When the renneted retentate was inoculated with ca $10^{6} \mathrm{cfu} / \mathrm{mL}$, data from SEM also indicated colonies, though smaller in size (than those when a lower inoculum level was used). However, in renneted milk ino- 


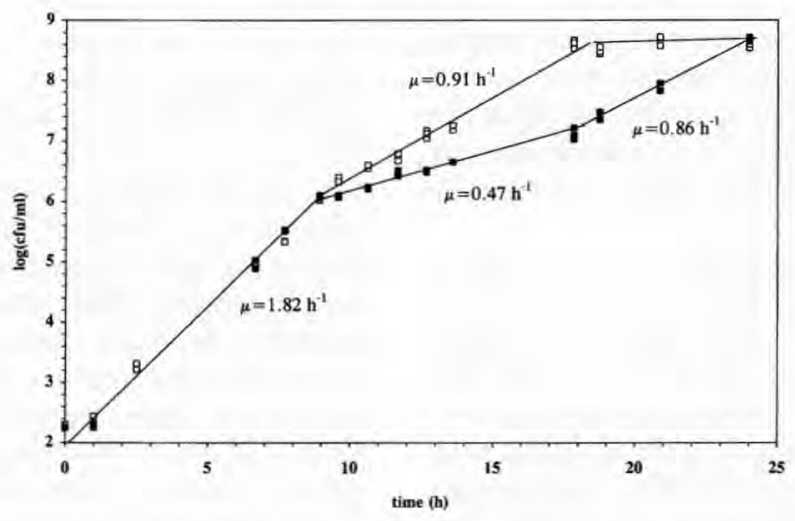

Fig 11. Growth of $L$ lactis CNRZ 1075 (prt) in milk ( $(\square)$ and in rennet curd (⿴) supplemented with $2 \mathrm{mg} / \mathrm{mL}$ casein hydrolysate (Casitone, Difco, Detroit, USA). The level of inoculation was $10^{2} \mathrm{cfu} / \mathrm{mL}$. Croissance de L lactis CNRZ 1075 (prt) dans le lait (כ) et dans le coagulum présure (ש) supplémentés avec $2 \mathrm{mg} / \mathrm{mL}$ d'hydrolysat de caséines (Casitone, Difco, Detroit, Etats-Unis). Le taux d'inoculation était de $10^{2}$ ufc/mL.

culated at this level, there was no evidence for individual colonies: bacteria were disseminated throughout the rennet curd, likely because of a lower diffusion of bacteria through the renneted retentate than through the renneted milk.

A possible explanation for the inhibition of $L$ lactis culture grown from low inocula is therefore the colonial growth structure. The lower the inoculum level, the more individual and larger the colonies. The colony diameters observed in cultures grown from low inocula were ca 200-300 $\mu \mathrm{m}$. Cachon and Diviès (1993) showed that the lactococcal cell density in gel beads in a depth of about $150 \mu \mathrm{m}$ was ca $75 \%$ of that found at the bead periphery. From the results on inhibition in liquid and renneted curd it is reasonable to suggests that growth in large colonies was inhibited as soon as colonies achieved a critical population size (ca $310^{4}$ cells). The inhibition (at a population of ca $310^{6} \mathrm{cfu} / \mathrm{mL}$ ) of the prt strain culture grown in liquid and renneted milk inoculated with $10^{2} \mathrm{cfu} / \mathrm{mL}$ suggest that cells in the centre of the expanding microcolony are being inhibited. According to studies about lactococcal cell density in gel beads (Yabannavar and Wang, 1991) lactose is likely not the limiting factor since it is present in medium in high concentrations (ca $50 \mathrm{~g} / \mathrm{L}$ ) and therefore can diffuse fast enough into the centre. However, it is possible that cells in the centre of colonies did not get sufficient essential amino acids in available form (ie, small peptides), depleted by cells in the periphery. Surprisingly, data in our study indicate that amino acids and peptides from pancreatic digest of casein failed to relieve the inhibition of the prt strain cultures grown from low inocula. A more precise study concerning the effect of addition of known quantities of essential amino acids on the growth of $L$ lactis CNRZ 1075 (prt) in low inoculated milk could validly explain the results.

In cultures of the prtt strain grown in liquid milk from low inocula, no decrease in growth rate occurred when the population level in culture increased by ca $10^{4} \mathrm{cfu} / \mathrm{mL}$ over the initial population. It should be assumed that the colonial growth structure could not on its own account for the inhibition observed in low level inoculated rennet 
curd. One can imagine that another condition, the decreased diffusion of solutes through the rennet curd, was necessary to inhibit cultures of the prt'strain grown from low inocula. Possible solutes involved are as follows:

-i) Though L lactis can use whey proteins $(\beta$-lactoglobulin and to a lesser extent $\alpha$-lactalbumin), casein is the main nitrogen source for growth in milk (Mills and Thomas, 1981). In renneted milk, casein micelles are immobilized and one can wonder if they are still available to $L$ lactis cells grown in colonies. According to figure $6 \mathrm{a}$, $b$, this nitrogen source is located outside of the colony and seems unavailable to $\mathrm{L} \mathrm{lac}$ tis cells in its centre. However, since addition of pancreatic digest of casein failed to relieve the inhibition in rennet curd inoculated with low level, it is unlikely that immobilization of caseins micelles could play a role in the decrease in growth rate.

- ii) It has already been reported that the diffusion coefficient of salts such as $\mathrm{NaCl}$ is five-fold reduced in cheese moisture as compared to that in pure waters (Geurts et al, 1974). Because of the limited diffusion of protons through the rennet curd, a possible reason for the occurrence of growth inhibition of $L$ lactis CNRZ 1076 when colony populations increased beyond the critical size is possibly the rapid decrease of $\mathrm{pH}$ near the colonies. Observations on rennet curd to which $2 \mathrm{mg}$ bromocresol purple/100 $\mathrm{mL}$ was added presented evidence for concentration of protons in the vicinity of the colonies since this blue $\mathrm{pH}$ indicator turned to yellow more quickly at the periphery of colonies than in the middle of the curd (unpublished results). Yabannavar and Wang's study (1991) showed that the use of large beads in order to immobilize cells of Lactobacillus delbrüeckii led to significant build-up of inhibitory products, ie, proton and lactate.

The microstructure of the network also supports the assumption that the $\mathrm{pH}$ values were much lower in the vicinity of the colo- nies than in the middle of the curd. Aggregation and concentration of casein micelles actually occurred in a sample of $\mathrm{pH} 6.30$, whereas these phenomena usually indicate a $\mathrm{pH}$ value lower than 5.20-5.10 (Heertje et al, 1985), if it is assumed that the renneting of milk does not perturb these rearrangements. The growth of lactic acid bacteria is generally affected by a decrease in the $\mathrm{pH}$ of the medium (Longsworth and Mac Innes, 1936; Harvey, 1965; Hugenholtz et al, 1987). The decrease in external $\mathrm{pH}$ finally leads to a decrease in internal $\mathrm{pH}$ which affects the activities of many enzymes (Kashket, 1987) and also perturbs the transport systems (Poolman et al, 1987). Nevertheless, addition of $20 \mathrm{mmol} / \mathrm{L}$ calcium phosphate buffer to renneted milk culture medium (final concentration) did not have any restoring effect on inhibited growth rate, which led us to suggest that bacteria in colonies were not inhibited by the local decrease in $\mathrm{pH}$. This assumption was supported by the observation on growth inhibition in renneted VCR 3 retentate. Despite the higher buffering capacity of the medium, the inhibition ratio of $L$ lactis CNRZ 1076 was unchanged compared to that found in renneted milk.

- iii) Moreover, one can suppose that the increase in solubilized micelle bound phosphate concentration on local acidification near the colonies could play a role in the growth inhibition observed in rennet curd inoculated at a low level. Indeed, previous studies (Bergère and Hermier, 1968; Ledford and Speck, 1979; Wright and Klaenhammer, 1984) have shown that some lactic acid bacteria were injured when grown in milk and culture media containing at least $100 \mathrm{mmol} / \mathrm{L}$ phosphate. However, the concentration of soluble phosphate in acidified milk is limited to an upper value of $25 \mathrm{mmol} / \mathrm{L}$ (Le Graet and Brulé, 1993). On the basis of these observations, unless phosphate is concentrated in bacterial colonies, it seems unlikely that it could inhibit the growth of $L$ lactis $C N R Z$ 
1076. According to the Nernst equation, accumulation of phosphate in colonies depends on the existence of a positive electrical potential between colonies and curd. Because of high conductivity of acidified milk (> $5010^{-4}$ mho, Alais, 1984) generation of a ca 150 A current by colonies would be necessary to obtain a four-fold higher concentration of phosphates in colonies as compared to their concentration in curd!

- iv) Another explanation for the growth inhibition of $L$ lactis CNRZ 1076 observed in rennet curd is related to a possible increase of lactate concentration near the bacterial colonies. According to the energy recycling model (Michels et al, 1979), it is well known that a lactate gradient across the cytoplasmic membrane results in the excretion of one molecule of lactate in symport with more than one proton. The generated electrochemical proton gradient was shown to increase both the amount of energy obtained in cells per mol of lactose and of uptake of the amino acid leucine (Otto et al, 1980). With increasing external lactate concentration, the $\mathrm{H}^{+} /$lactate stoichiometry decreased from 2 to 1 , resulting in a negligible energy gain. On the basis of observations on $\mathrm{H}^{+}$diffusion through rennet curd, it is reasonable to suppose that rennet curd around the colonies also limits diffusion of lactate. This would lead to a high concentration close to the cells and a possible decrease in growth rate. In liquid milk, however, no inhibition of growth in colonies was observed since $\mathrm{H}^{+}$and possibly also lactate could rapidly diffuse. More detailed information on both lactate concentration in the vicinity of colonies and $\mathrm{H}^{+} /$lactate stoichiometry as related to the growth rate depletion have to be obtained to support this hypothesis.

\section{ACKNOWLEDGMENTS}

The authors are indebted to J Berrier, P Boyaval, H Goudédranche, S Lortal, MN Madec, D Mollé and P Schuck for advice and help.

\section{REFERENCES}

Alais C (1984) Principes des techniques laitières. Science du lait, 4ème edn, SEPAIC, Paris

Baer A, Ryba I, Grand M (1992) Ursachen der Enstehung von brauner Tupfen im Käse. Schweiz Milchw Forschung 22, 3-7

Bergère JL, Hermier J (1968) La production massive de cellules de streptocoques lactiques. II Croissance de Streptococcus lactis dans un milieu à $\mathrm{pH}$ constant. Lait 48, 13-31

Burri R (1898) Ueber das Vorkommen relativ grosser Bakterienkolonien in Fehlerhaftem Emmentalerkäse. Zentralbl Bakteriol Abt II 4, 608-615

Cachon R, Diviès C (1993) Localization of Lactococcus lactis ssp lactis bv diacetylactis in alginate gel beads affects biomass density and synthesis of several enzymes involved in lactose and citrate metabolism. Biotechnol Tech 7, 453-456

Dean MR, Berridge NJ, Mabbitt LA (1959) Microscopical observations on Cheddar cheese and curd. J Dairy Res 26, 77-81

Garnot P, Mollé D (1982) influence de la nature et du taux d'inactivation sur le dosage de la chymosine ef de la pepsine bovine par immuno-diffusion. Lait 62 , 671-680

Gavaric DD, Caric M, Kalab M (1989) Effects of protein concentration in ultrafiltration milk retentates and the type of protease used for coagulation on the microstructure of resulting gels. Food Microstruct $8,53-$ 66

Geurts TJ, Walstra P, Mulder H (1974) Transport of salt and water during salting of cheese. 1 . Analysis of the process involved. Neth Milk Dairy J 28, 102-129

Hansson E, Olsson H, Sjöström G (1966) Mikrophotographie des Käsestruktur. Milchwissenschaft 21 , $331-334$

Harvey RJ (1965) Damage to Streptococcus lactis resulting from growth at low $\mathrm{pH}$. J Bacterio/ 90, 13301336

Heertje I. Visser J, Smits P (1985) Structure formation in acid gels. Food Microstruct 4, 267-277

Hugenholtz J, Splint R, Konings WN, Veldkamp H (1987) Selection of protease positive and protease negative variants of Streptococcus cremoris. Appl Environ Microbiol 53, 309-314

Juillard V, Richard J (1989) Etude de l'interaction entre souches protéolytiques de streptocoques lactiques mésophiles et leurs variants non protéolytiques, au cours de leur croissance dans le lait. Lait 69, 291304

Juillard V, Laan H, Bruins A, Konings WN (1994) Use of LC/MS for the identification of bovine $\beta$ casein peptides generated by purified cell-envelope located proteinase of Lactococcus lactis subsp cremoris WG2 (PI-type). Poster 6th Colloque des Bactéries Lactiques, Universite Claude Bernard, Lyon

Karel SF, Robertson CR (1989) Autoradiographic determination of mass-transfer limitations in immobilized cell reactors. Biotechnol Bioeng 34, 320-336 
Kashket E (1987) Bioenergetics of lactic acid bacteria: cytoplasmic $\mathrm{pH}$ and osmotolerance. FEMS Microbiol Rev 46, 233-244.

Konings WN, Poolman B, Driessen AJM (1989) Bioenergetics and solute transport in lactococci. CRC Crit Rev Microbiol 16, 419-476

Ledford RA, Speck ML (1979) Injury of lactic streptococci by culturing in media containing high phosphates J Dairy Sci 62, 781-784

Le Graet Y, Brulé G (1993) Les équilibres minéraux du lait : influence du $\mathrm{pH}$ et de la force ionique. Lait 73 , $51-60$

Longsworth LG, Mac Innes Da (1936) Quantitative studies on the physiology of Lactobacillus acidophilus. J Bacterio/ 31, 287-300.

Michels PAM, Michels JPJ, Boonstra J, Konings WN (1979) Generation of an electrochemical proton gradient in bacteria by the excretion of metabolic end products. FEMS Microbiol Lett 5, 357-364

Mills OE, Thomas TD (1981) Nitrogen sources for growth of lactic streptococci in milk. NZ J Dairy Sci Technol 16, 43-55

Monod J (1958) Recherches sur la croissance des cultures bactériennes. Hermann, Paris

Naylor J, Sharpe E (1958) Lactobacilli in Cheddar cheese. 1. The use of selective media for isolation and of serological typing for identification. J Dairy Res 25, 92-103

Otto R, Sonnenberg ASM, Veldkamp $\mathrm{H}$, Konings WN (1980) Generation of an electrochemical proton gradient in Streptococcus cremoris by lactate efflux. Proc Natl Acad Sci USA 77, 5502-5506

Poolman B, Driessen A, Konings WN (1987) Regulation of solute transport in streptococci by external and internal $\mathrm{pH}$ values. Microbiol Rev 51, 498-508

Postgate JR, Crumpton JE, Hunter JR (1961) The measurement of bacterial viabilities by slide culture. J Gen Microbiol 24, 15-24

Prokopek D, Knoop AM, Buchheim W (1976) Elektronenmikroskopische Untersuchungen at Ultrafiltra- tionskonzentraten aus Magermilk und daraus hergestelltem Käse. 2. Sensorische Eigenschafter und Feinstrukture bei Camembert Käsen. Kiel Milchwirtsch Forschungsber 28, 245-268

Reiter B, Oram JD (1962) Nutritional studies on cheese starters. Vitamin and amino acid requirements of single strain starters. J Dairy Res 29, 63-77

Rogers LA, Whittier EO (1928) Limiting factors in the lactic fermentation. J Bacteriol 16, 211-229

Rousseau M (1988) Changes in the microstructure of Saint Paulin cheese during manufacture studied by scanning electron microscopy. Food Microstruct 7 , 105-113

Rousseau M, Le Gallo C (1990) Etude de la structure de l'Emmental au cours de la fabrication, par la technique de microscopie à balayage. Lait 70, 55-66

Schuck P, Piot M, Méjean S, Fauquant J, Brulé G, Maubois JL (1994) Déshydratation des laits enrichis en caséine micellaire par microfiltration, comparaison des propriétés des poudres obtenues avec celles d'une poudre de lait ultra-propre. Lait 74, 47-63

Smid EJ, Poolman B, Konings WN (1991) Minireview: Casein utilization by lactococci. Appl Environ Microbiol $57,2447-2452$

Thöni J, Alleman O (1910) Über das Verkommen von gefärbten, makroskopischen Bakterienkolonien in Emmentalerkäsen. Zentralb/ Bakterio/ 25, 8-31

Turner N, Sandine WE, Elliker PR, Day GA (1963) Use of tetrazolium dyes in an agar medium for differentiation of Streptococcus lactis and Streptococcus cremoris. J Dairy Sci 46, 380-385

Wright CT, Klaenhammer TR (1984) Phosphated milk adversely affects growth, cellular morphology and fermentative ability of Lactobacillus bulgaricus. J Dairy Sci 67, 44-51

Yabannavar VM, Wang DIC (1991) Analysis of mass transfer for immobilized cells in an extractive lactic acid fermentation. Biotechnol Bioeng 37, 544-550 